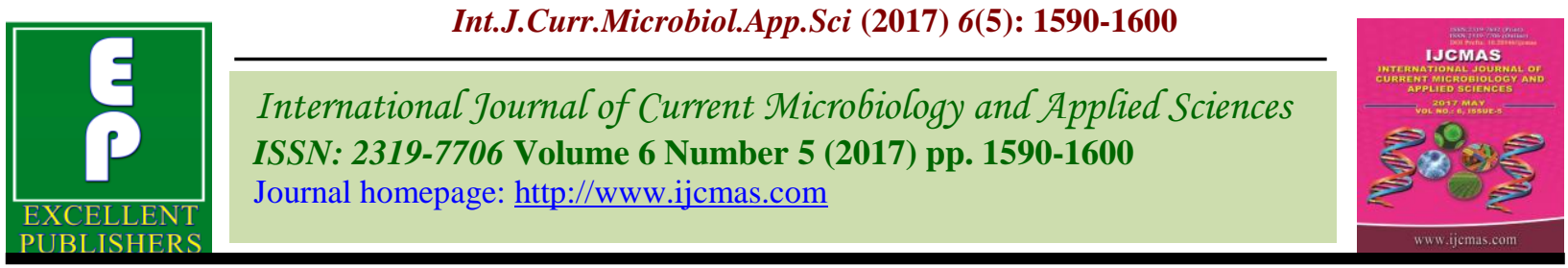

Original Research Article

https://doi.org/10.20546/ijcmas.2017.605.173

\title{
Impact of Urbanisation on Natural Regeneration of Shorea robusta in Doon Valley (India)
}

\author{
Prateek Srivastava* and H.B. Vasistha \\ Ecology, Climate Change and Forest Influence Division, Forest Research Institute (FRI), \\ Dehradun (Uttarakhand) 248006 India \\ *Corresponding author
}

\section{A B S T R A C T}

Keywords

Regeneration, Urbanisation, Forest restoration, Shorea robusta, Assisted Natural Regeneration.

Article Info

Accepted:

17 April 2017

Available Online:

10 May 2017
Natural regeneration is an inherent ability of floral species to reproduce and proliferate and is a clear indicator of health of forest ecosystem. The community forestry movement has had a positive impact on natural regeneration. The present study focuses on Assisted Natural Regeneration (ANR), also a form of community forestry which assists natural forest regeneration through an arrangement of fire prevention techniques and control on anthropogenic activities by applying various physical barriers. It essentially emphasizes the significance of forest fire management, protection against destructive grazing and assisting the development of naturally occurring tree seedlings in numerous ways. An ANR site 'Chandpur-5' of $S$. robusta or Sal forest covering an area of 25 hectare located in Kalsi Forest Division in Dehradun Valley, Uttarakhand (India) was selected and the study discusses the associated demographic pressure and consequently exhibiting current state of regeneration in non ANR adjoining area, comparing both. The results obtained within the ANR were found unsatisfactory. The program does not seem being implemented in exact approach and applied dynamically within the country. Reasons for this may comprise lack of understanding about forestry and forest ecology, a stubbornness of approach from funding bodies and lack of incentives for rural communities to care for the forests. Development and expansion of cities towards forest with unplanned urbanization policies as well as high density of population in vicinity of forest for agriculture is creating tremendous pressure, resulting in illicit removal of forest resources as well as encroachment of forestland.

\section{Introduction}

Sal (Shorea robusta Gaertn. f.) occurs gregariously on the southern slopes of the Himalayas and is distributed in Bangladesh, India and Nepal (Figure 1). Sal is one of the major timber-yielding plant species in India, known for its superior quality wood (Satya $e t$ al., 2005). S. robusta forests are among the most disturbed types of forest in Southeast Asia (Sapkota et al., 2009), due to their high timber value and socio-economic importance for fodder, fuel-wood, leaf litter and minor forest products.

In India, Sal forests form a major source of timber and are managed for commercial timber production to increase revenue (Gautam and Devoe, 2006). During the past decades, there was massive deforestation to use the wood as railway sleepers, shipbuilding and other purposes. Past records 
provide evidence of larger distribution of Sal forests in the northern and eastern parts of India (O'Malley, 2011), and their eventual clearance for expanding agriculture, human settlements, etc. (Negi, 1994). Sal forests yield non-timber forest products, including fodder (Edwards, 1996), seed for oil, tannin and gum from bark (Narayanmurti and Das, 1951) and leaves for plate making. The frequent and fluctuating type of disturbance in such forests, and its causes, have been investigated for decades in India (Pandey and Shukla, 2001; Sagar et al., 2003) and in Nepal (Webb and Sah, 2003; Timilsina et al., 2007; Sapkota et al., 2009). During the early 1960s some of the peripheral dry deciduous forests were subjected to clear felling, these areas were reforested by fast growing species such as Eucalyptus spp., Dalberjia sissoo, Acacia catechu, Ailanthus excelsa and Populus spp. to cater to the need of the industry. But during 1980s these forests were again harvested for the settlement of people displaced from Tehri Hydro-electrical project area and some other industrial developments. This kind of change in land use pattern has caused micro-climatic disturbances mainly as a result of increase in solar radiation reaching the forest floor.

ANR is a simple, low-cost forest restoration measure that can effectively convert degraded fragile land to more productive forests. The method aims to accelerate, rather than replace, natural successional processes by removing or reducing barriers to natural forest regeneration such as soil degradation, competition with weedy species, and recurring disturbances (e.g., fire, grazing, and wood harvesting). Compared to conventional reforestation methods involving planting of tree seedlings, ANR offers significant cost advantages (Table 1) because it reduces or eliminates the costs associated with propagating, raising, and planting seedlings (Bansal et al., 2011). ANR techniques are flexible and allow for the integration of various values such as timber production, biodiversity recovery and cultivation of crops, fruit trees, and non-timber forest products in the restored forest. Shono et al., (2007) have conducted study in ANR areas of degraded tropical forests in Philippines. Systematic application of ANR and monitoring of forest development are needed to enhance the technique and to validate personal experiences with successful applications of the approach which lack in India. The ANR approach, under different names, has been implemented in combination with other forest restoration methods in China, Nepal, Ethiopia, Nigeria, and Sri Lanka (Bay, 2002; Sannai, 2003).

\section{Policy and politics of land use: Chronology of past events}

Uttarakhand, a hill state, was part of Uttar Pradesh before November, 2000. Forest Management in the region is affected by Forest Acts and Policies that apply to the whole country as well as by those specific to the state. The chronology of major events in forest management in this tropical forestland is as follows:

1855 The Charter of Indian Forestry to restrict and regulate unchecked exploitation of forests by private individuals.

1865 The Indian Forest Act, 1865 was passed for protection of forests. The act marked greater control of State over forest resources.

1878 The Indian Forest Act, 1878 replaced the latter. The forests categorised in Reserves, Protected and Village forests. Village forests created from Reserve forests for subsistence of locals.

1894 The Forest Policy acquainted for maintenance of adequate forest cover was recognized keeping in mind 
climatic and physical conditions of the country. Land Acquisition Act was also introduced.

1927 The Indian Forest Act, 1878 was reenacted. Amendments included duty on timber. Provisions were made to create village forests within reserve forests.

1931 A set of rules for the management of Panchayat Forests was notified.

1935 The Indian National Park Act was promulgated leading to formation of India's first national park.

1948 The UP Private Forest Act was introduced. It regulated use of land under private ownership with forest land, wasteland or lands uncultivated for seven years or more.

1952 First Forest Policy after independence was announced emphasising ecological and social aspects of forestry. It stressed to the needs of locals as well without any compromise but not at the expense of national interest.

1972 The Wildlife Protection Act was promulgated for conservation of wild animals.

U.P. Panchayat Forest Act 1972, used provisions of Indian Forest Act 1927 for formation of Village forest.

1974 The U.P. Forest Corporation Act 1974 was introduced focussing to create a corporation associated with removal and disposal of forest products like timber and tendu leaves.

1976 The U.P. Resin and other forest produce Act of 1976 dealing mainly with sale and purchase of resin.

The Van Panchayat Rule of 1972 was amended.

The National Commission on Agriculture (NCA) advocated change from conservation oriented forestry to a more dynamic programme of production forestry. Social forestry schemes were also started.

1980 The Forest Conservation Act of 1980 prohibited the use of forest land for non forestry purposes and also establishment of plantations of horticultural crops without prior permission.

1981 On March 18 1981, felling of green trees was banned in U.P. hills above 1000 masl.

1988 The Forest Policy of 1988 was introduced which gave high priority to environmental concerns than earning revenue. Encouraged mixed forest over monoculture. Indicated need to involve locals for conservation of forests.

1990 Resolution issued by Government of India on June 11990 made possible for forest department to involve communities in forest management and also share economic benefits.

1997 The U. P. Village Forest Joint Forest Management Rules of 1997 were promulgated and allowed direct economic benefits to the beneficiaries of forest management instead of Van Panchayat rules where benefit was for Van Panchayat body.

The draft Van Panchayat Rules 1997 were prepared to replace the 1976 Rules.

The timeline of development of forest acts, policies and land settlements, clearly shows that the government has been increasingly concerned about the conservation of the country's forests. Although, no separate policy has been announced for the hills, specific references have been made within the general forest policy of the country (ICIMOD, 2000).

\section{Change factors and the nature of degradation}

Large scale introduction of agriculture affected tree cover where the terrain was plain 
and water supply was dependable as in the Gangetic plains. However, most of the hilly, dry and malarious tracts like the Terais appeared to have remained under a good forest cover till the arrival of British. On consolidating their hold over India, the British began to lay down an extensive network of railway lines to facilitate the export of raw materials from and the import of finished goods to the remote corners of the country. There are, however, a few exceptions, particularly when the unreserved forest was directly under the control of cohesive village community and not under the control of revenue authorities. Thus, there were many Van Panchayat forests in the Tehri-Garhwal areas of the Himalayas which were fully controlled by the local communities and are better preserved than the Reserve Forests of the tract (Gadgil et al., 1983).

\section{Present Management}

ANR forms the major strategy of treating degraded forest through Joint Forest Management (JFM) approach under the National Afforestation Programme (NAP) and Externally Aided Forestry Projects (EAP). It is the dominant plantation model of forest treatment in India. ANR in India is treated as a tool of afforestation. It forms the dominant component of the NAP, Government of India's flagship afforestation program. NAP aims to support and accelerate the ongoing process of devolving forest protection, management and development functions to decentralized institutions of Joint Forest Management Committee (JFMC) at the village level (Bansal et al., 2011).

\section{Question}

Whether ANR techniques being implemented in community forest management programs to support natural regeneration of $S$. robusta by Uttarakhand Forest Department are adequate and facilitating healthy behaviour of naturally regenerating Sal forests of Dehradun region?

\section{Materials and Methods}

\section{Study area}

The ANR initiative in Kalsi Forest Division was introduced under the proposed project of Kalsi Soil Conservation Division in 1999 to safeguard the natural tropical Sal forest of the vicinity and the plot was also marked in the same year. Protected area or the ANR plot selected for the study is Chandpur-5 of 25 ha area. Chandpur-5 is situated between longitude $77^{\circ} 49^{\prime} 43^{\prime \prime}$ to $77^{\circ} 50^{\prime} 14^{\prime \prime} \mathrm{E}$ and latitude $30^{\circ} 24^{\prime} 03^{\prime \prime}$ to $30^{\circ} 23^{\prime} 50^{\prime \prime} \mathrm{N}$ at an elevation of about $520 \mathrm{~m}$ asl and falls under Kalsi Forest Division, Uttarakhand (India).

The area is located $2 \mathrm{~km}$ from Sahaspur town and $30 \mathrm{~km}$ from Dehradun (Fig. 2). Although the temperature in Dehradun can reach below freezing during severe cold snaps, summer temperatures can reach up to $44{ }^{\circ} \mathrm{C}$ for a few days and hot wind called 'Loo' blows over North India, whereas winter temperatures are usually between 1 and $20^{\circ} \mathrm{C}$ and fog is quite common in winters like plains. Dehradun experiences severe rain showers with $2200 \mathrm{~mm}$ of rainfall approximately between June and September, according to Director of the Dehradun Meteorological Centre. Sahaspur is a densely populated area and has1134 households with a total population of 6568 individuals approximately. As per the programme, Chandpur-5 is completely protected from anthropogenic disturbances, whereas, the adjoining unprotected plot is still exposed to it. The unprotected site is located adjoining Chandpur-5. The unprotected area is situated between longitude $77^{\circ} 49^{\prime} 19^{\prime \prime}$ to $77^{\circ} 49^{\prime} 42^{\prime \prime} \mathrm{E}$ and latitude $30^{\circ} 24^{\prime} 09^{\prime \prime}$ to $30^{\circ} 23^{\prime} 46^{\prime \prime} \mathrm{N}$ covering an area of 28 hectare, at an elevation of about $515 \mathrm{~m}$ asl. 


\section{Methodology}

Data were collected at two separate sites in the month of January at Kalsi Soil Conservation Division. The analysis was carried out by placing 20 nested quadrats out of which 10 quadrats placed at protected and 10 at unprotected site in which quadrats of 10 x $10 \mathrm{~m}, 3 \times 3 \mathrm{~m}$ and $1 \times 1 \mathrm{~m}$ are placed progressively from smaller to larger squares with a common centre point.

The density (individuals/hectare) for Sal trees, Sal saplings and seedlings were analysed. The state of regeneration of sampled species was assessed based on one time phytosociological data in the following categories (Khan et al., 1987):

Good regeneration, if seedlings >saplings $>$ adults

Fair regeneration, if seedlings $>$ or $\leq$ saplings $\leq$ adults

Poor regeneration, if Sal survives only in sapling stage, but not as seedlings (though saplings may be less, more or equal to adults)

No regeneration, if Sal is absent both in sapling and seedling stages, but present as adults

New, if Sal has no adults, but only saplings and/or seedlings

\section{Results and Discussion}

In protected area or the ANR, as far as $S$. robusta is concerned, 26 individual trees were found in 10 quadrats marked with a density of 260 individuals/ ha, 4 individual saplings found in 10 quadrats marked with density of 1.33 individuals $/ 100 \mathrm{~m}^{2}$ and 2 seedlings were found in 10 quadrats marked with density of mere 0.4 individuals/ $\mathrm{m}^{2}$. This clearly confirms that adults >saplings >seedlings, representing 'Fair' regeneration, whereas, in the unprotected area there were 29 trees present in tree layer found in 10 quadrats studied marking a density of 290 individuals/ ha, 7 individuals found in Shrub layer in 10 quadrats studied depicting density of 2.33 individuals/ $100 \mathrm{~m}^{2}$ and 1 individual only found in seedlings in 10 quadrats studied which shows a density of 0.1 individuals $/ \mathrm{m}^{2}$, representing adult $>$ saplings $>$ seedlings, also depicting 'Fair' regeneration. All over, status of regeneration is better in unprotected than in protected.

Although, protected area recorded 23 Families, whereas, unprotected area confirm only 19 Families depicting a greater diversity in the ANR, it is clear from the above that there are more number of adults, seedlings and saplings present in the unprotected area as compared to the protected area. Sal has a good number of saplings, but not of seedlings. Condition of number of seedlings is better in unprotected than in protected area.

Phytosociological data of protected (ANR) and unprotected site showing Species, Family, Total number of individuals of a species, Density per hectare and Importance Value Index (IVI) are tabulated below.

When we analyse Figure 3 for IVI and tables between Protected and Unprotected areas, it clearly give a picture of decline in the value of both sapling and seedling stages. Same trend can be visualized in figures 3 and 4 estimating Total No. of Individuals.

The situation worth noticing is that the values are less in the protected areas than the unprotected areas which ideally should have been the other way round. This clearly shows that there is certainly a form of mismanagement being followed within the programme which needs to be rectified in order to make regeneration for the species towards positive. 
Int.J.Curr.Microbiol.App.Sci (2017) 6(5): 1590-1600

Table.1 Advantages of ANR in Southeast Asia

\begin{tabular}{|l|l|}
\hline Aspects & Advantages \\
\hline Economic & Faster and cheaper; no need to establish a nursery. \\
\hline $\begin{array}{l}\text { Ecological } \\
\text { (biodiversity and } \\
\text { local ecological } \\
\text { knowledge } \\
\text { perspectives) }\end{array}$ & $\begin{array}{l}\text { Promotes and conserves biodiversity; maintains the natural } \\
\text { maintains integrity of the soil and involves minimum soil } \\
\text { disturbance; promotes hydrologic integrity and biotic } \\
\text { functions; promotes use of indigenous knowledge (IK); helps } \\
\text { blending of traditional knowledge with modern scientific } \\
\text { forestry. }\end{array}$ \\
\hline $\begin{array}{l}\text { Social } \\
\text { (community } \\
\text { participation, } \\
\text { empowerment } \\
\text { livelihoods } \\
\text { perspectives) }\end{array}$ & $\begin{array}{l}\text { Treats local communities as an integral part; labour } \\
\text { intensive; provides employment for the local community; } \\
\text { promotes empowerment if IK and traditional institutions are } \\
\text { used and valued; effective in remote locations where } \\
\text { government approaches have not been very successful. }\end{array}$ \\
\hline
\end{tabular}

Table.2 Species, Density and IVI in Tree, Shrub and Herbaceous Layers at Protected Area (ANR)

\begin{tabular}{|lllccc} 
S.No & Name of species & Family & $\begin{array}{c}\text { Total no of individuals } \\
\text { of species }\end{array}$ & Density & IVI \\
\hline Tree Layer & & Indi./ ha & & \\
\hline $\mathbf{1}$ & Shorea robusta & Dipterocarpaceae & 26 & 260 & 281.23 \\
$\mathbf{2}$ & Terminalia tomentosa & Combretaceae & 1 & 10 & 18.77
\end{tabular}

\begin{tabular}{lllll} 
Shrub Layer & & Indi./ $\mathbf{1 0 0} \mathbf{~ m}^{\mathbf{2}}$ & \\
\hline $\mathbf{3}$ & Jasminum sp & Oleaceae & 76 & 25.31 \\
$\mathbf{4}$ & Clerodendrum viscosum & Lamiaceae & 48 & 15.98 \\
$\mathbf{5}$ & Millettia pinnata & Fabaceae & 45 & 14.99 \\
$\mathbf{6}$ & Murraya koenigii & Rutaceae & 31 & 10.32 \\
$\mathbf{7}$ & Syzygium cumini & Myrtaceae & 12 & 4.00 \\
$\mathbf{8}$ & Ardisia solanacea & Primulaceae & 11 & 3.66 \\
$\mathbf{9}$ & Mallotus philippensis & Euphorbiaceae & 9 & 3.00 \\
$\mathbf{1 0}$ & Shorea robusta (sapling) & Dipterocarpaceae & 4 & 1.33 \\
$\mathbf{1 1}$ & Carisa carandas & Apocynaceae & 4 & 1.33 \\
$\mathbf{1 2}$ & Flacourtia indica & Salicaceae & 3 & 1.00
\end{tabular}


Int.J.Curr.Microbiol.App.Sci (2017) 6(5): 1590-1600

$\begin{array}{lllll}\mathbf{1 3} & \text { Cordia myxa } & \text { Boraginaceae } & 2 & 0.67 \\ \mathbf{1 4} & \text { Flemingia strobilifera } & \text { Fabaceae } & 1 & 0.33 \\ \mathbf{1 5} & \text { Ehretia laevis } & \text { Boraginaceae } & 1 & 0.33 \\ \mathbf{1 6} & \text { Vallaris solanacea } & \text { Apocynaceae } & 1 & 0.33 \\ \mathbf{1 7} & \text { Achyranthes aspera } & \text { Amaranthaceae } & 1 & 0.33\end{array}$

$\begin{array}{lllll}\text { Herbaceous Layer } & & \text { Indi. / m} & \\ \mathbf{1 8} & \text { Echinocarpus } s p & \text { Elaeocarpaceae } & 4 & 0.3 \\ \mathbf{1 9} & \text { Jasminum } s p & \text { Oleaceae } & 4 & 0.4 \\ \mathbf{2 0} & \text { Urena lobata } & \text { Malvaceae } & 4 & 0.2 \\ \mathbf{2 1} & \text { Curculigo orchioides } & \text { Hypoxidaceae } & 3 & 0.2 \\ \mathbf{2 2} & \text { Solanum khasianum } & \text { Solanaceae } & 3 & 0.1 \\ & & & \\ \mathbf{2 3} & \text { Shorea robusta } \text { (seedling) } & \text { Dipterocarpaceae } & 2 & 0.4 \\ \mathbf{2 4} & \text { Desmodium cephalotes } & \text { Papilionaceae } & 2 & 0.3 \\ \mathbf{2 5} & \text { Clematis gouriana } & \text { Ranunculaceae } & 2 & 0.1 \\ \mathbf{2 6} & \text { Dioscorea sp } & \text { Lamiaceae } & 1 & 0.1 \\ \mathbf{2 7} & \text { Abrus precatorius } & \text { Fabaceae } & 1 & 0.1 \\ \mathbf{2 8} & \text { Oplismenus compositus } & \text { Poaceae } & 1 & 0.4 \\ \mathbf{2 9} & \text { Oxalis corniculata } & \text { Oxalidaceae } & 1 & 0.1 \\ \mathbf{3 0} & \text { Rungia pectinata } & \text { Acanthaceae } & 1 & 0.2 \\ \mathbf{3 1} & \text { Rubus ellipticus } & \text { Rosaceae } & 1 & 0.1\end{array}$

Table.3 Species, Density and IVI in Tree, Shrub and Herbaceous Layers at Unprotected Area

\begin{tabular}{|c|c|c|c|c|c|}
\hline S.No & Name of species & Family & $\begin{array}{l}\text { Total no of } \\
\text { individuals of } \\
\text { species }\end{array}$ & Density & IVI \\
\hline Tree 1 & & & Indi./ ha & & \\
\hline 1 & Shorea robusta & Dipterocarpaceae & 29 & 290 & 300 \\
\hline Shrul & yer & & Indi./ 10 & & \\
\hline 2 & Jasminum $s p$ & Oleaceae & 105 & 34.97 & \\
\hline 3 & Clerodendrum viscosum & Lamiaceae & 38 & 12.65 & \\
\hline 4 & Millettia pinnata & Fabaceae & 26 & 8.66 & \\
\hline 5 & Murraya koenigii & Rutaceae & 12 & 4.00 & \\
\hline 6 & Carisa carandas & Apocynaceae & 11 & 3.66 & \\
\hline 7 & Ardisia solanacea & Primulaceae & 9 & 3.00 & \\
\hline 8 & Randia dumetorum & Rubiaceae & 7 & 2.33 & \\
\hline 9 & Shorea robusta (sapling) & Dipterocarpaceae & 7 & 2.33 & \\
\hline 10 & Mallotus philippensis & Euphorbiaceae & 5 & 1.67 & \\
\hline 11 & Cordia myxa & Boraginaceae & 4 & 1.33 & \\
\hline 12 & Flacourtia indica & Salicaceae & 1 & 0.33 & \\
\hline 13 & Ehretia laevis & Boraginaceae & 1 & 0.33 & \\
\hline 14 & Flemingia strobilifera & Fabaceae & 1 & 0.33 & \\
\hline Herbz & us Layer & & Indi. / $\mathrm{m}^{2}$ & & \\
\hline 15 & Rungia pectinata & Acanthaceae & 4 & 0.4 & \\
\hline 16 & Urena lobata & Malvaceae & 4 & 0.4 & \\
\hline
\end{tabular}


Int.J.Curr.Microbiol.App.Sci (2017) 6(5): 1590-1600

$\begin{array}{lllll}\mathbf{1 7} & \text { Desmodium cephalotes } & \text { Papilionaceae } & 4 & 0.4 \\ \mathbf{1 8} & \text { Dioscorea sp } & \text { Lamiaceae } & 3 & 0.3 \\ \mathbf{1 9} & \text { Jasminum } s p & \text { Oleaceae } & 3 & 0.3 \\ \mathbf{2 0} & \text { Sida acuta } & \text { Malvaceae } & 2 & 0.2 \\ \mathbf{2 1} & \text { Achyranthes aspera } & \text { Amaranthaceae } & 1 & 0.1 \\ \mathbf{2 2} & \text { Clematis gouriana } & \text { Ranunculaceae } & 1 & 0.1 \\ \mathbf{2 3} & \text { Oplismenus compositus } & \text { Poaceae } & 1 & 0.1 \\ \mathbf{2 4} & \text { Cissampelos pareira } & \text { Menispermaceae } & 1 & 0.1 \\ \mathbf{2 5} & \text { Echinocarpus } \text { sp } & \text { Elaeocarpaceae } & 1 & 0.1 \\ \mathbf{2 6} & \text { Shorea robusta (seedling) } & \text { Dipterocarpaceae } & 1 & 0.1 \\ \mathbf{2 7} & \text { Leucas aspera } & \text { Lamiaceae } & 1 & 0.1 \\ \mathbf{2 8} & \text { Murraya koenigii } & \text { Rutaceae } & 1 & 0.1\end{array}$

Fig.1 Natural zones of Sal Forest (Shaded dots for Sal forests after Stainton, 1972; FAO, 1985)

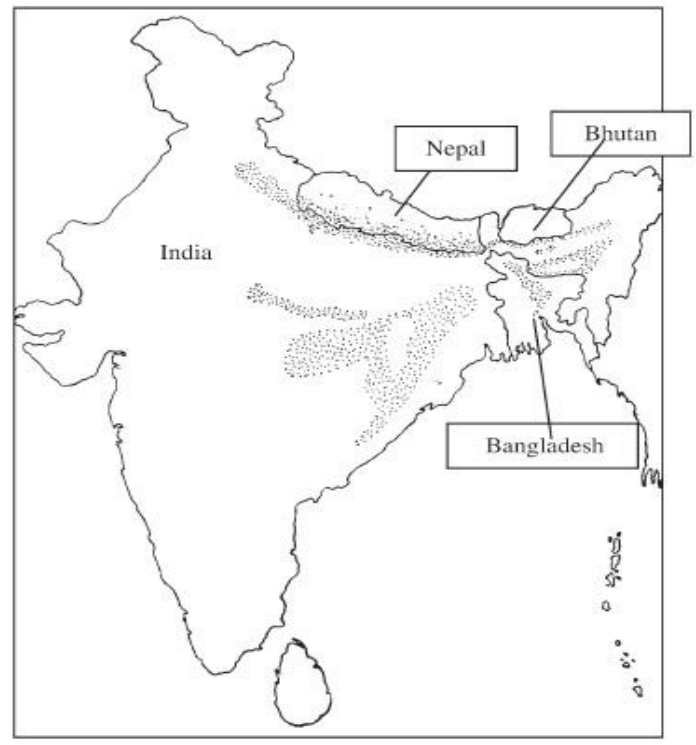

Fig.2 Preparation of mango nectar
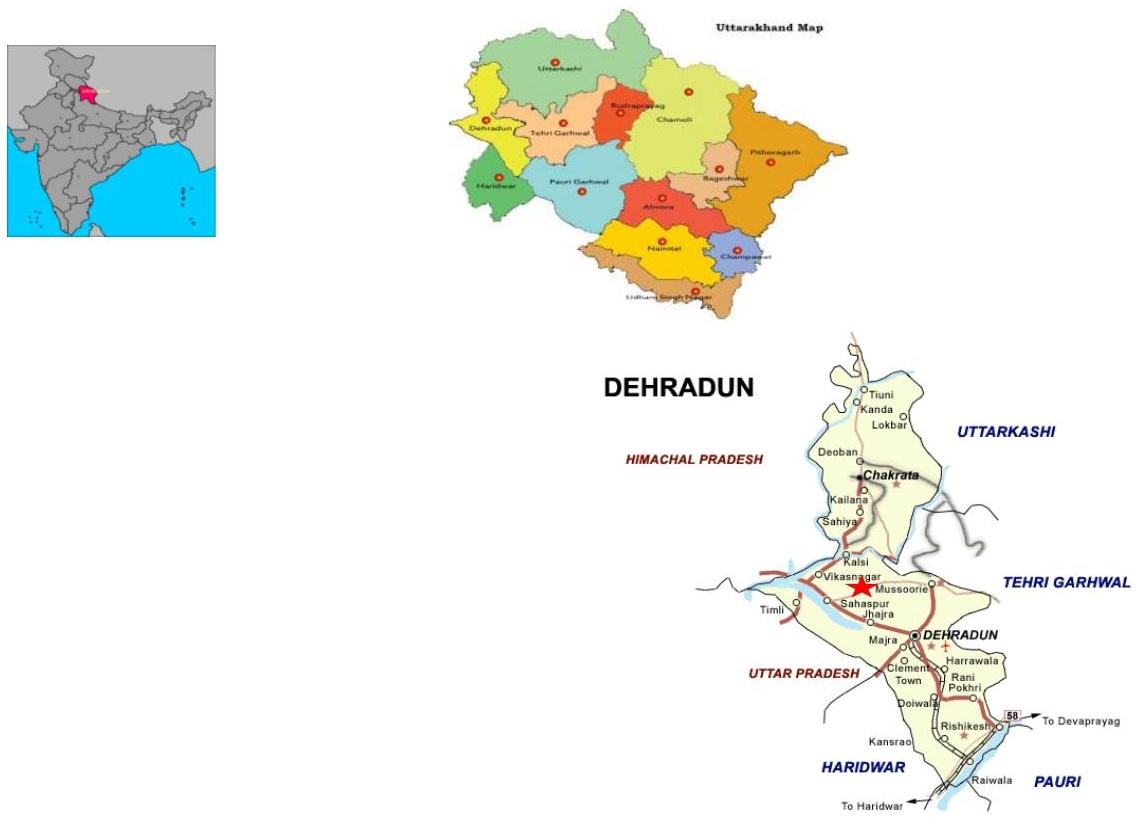
Fig.3\&4 Graphs comparing Total No. of Individuals and Density in Herbaceous Layer and Graphs comparing Total No. of Individuals and Density in Shrub Layer

Fig.3

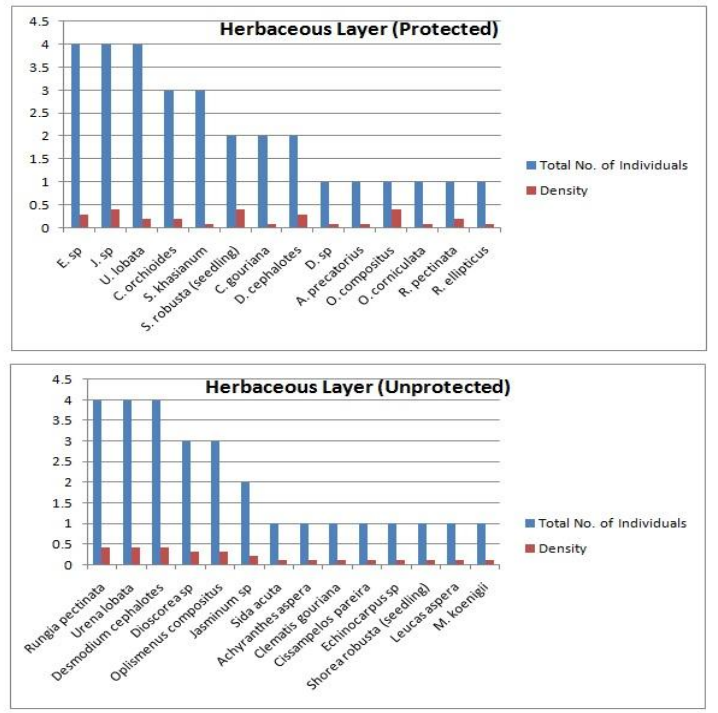

Fig.4
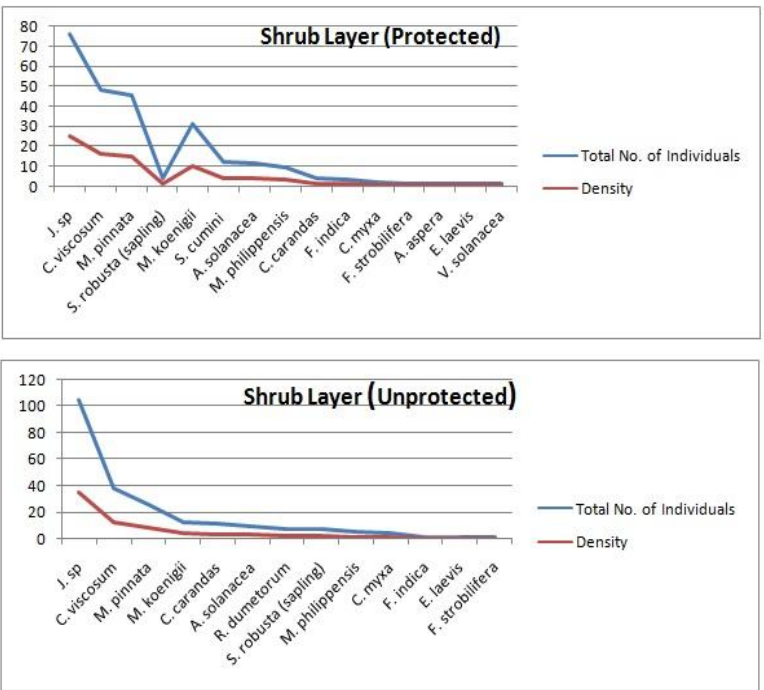

Fig.5 Graphs comparing Total No. of Individuals, Density and IVI in Tree Layer
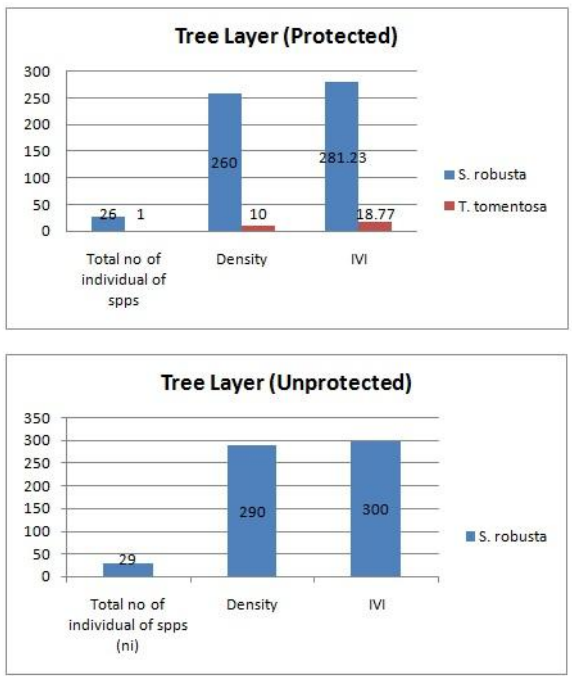

Impact of present management techniques

Although, the number of species in the ANR is greater than the unprotected area showing a good diversity but the area being a pure Sal (S. robusta) sub-tropical natural forest has 
very less IVI and density both in Shrub and Herbaceous layer showing a poor status of regeneration as compared to other associates of Sal. In shrub layer the situation is still alarming because in the protected ANR area the IVI is less as compared to the IVI of Sal in unprotected area. Keeping the status of standing crop and regeneration of S. robusta in particular it is concluded that though, the crop condition is quite good, regeneration does not seem adequate. Biotic influences, cattle grazing, fire and other hazards must be strictly controlled for the sustainable development of population structure of Sal even in ANR in spite of protection.

Despite its practical advantages, the technique remains underutilized due to lack of awareness and research demonstrating its effectiveness. The ANR plot is said to be protected from local animals by means of fencing, trenching and stone walls at many places but still cattle belonging to the local communities can easily be spotted grazing inside the protected area. Such activities can be stopped only with wise, scientific, and intensive management policies, its strict implementation and regular patrolling which will eventually save these Sal forests and associated resources, such as, fuel, fodder etc for a longer time. Apart from this, there are many more techniques, such used in programmes in Philippines which can be applied. Future managers should aim at managing them simultaneously for multiproducts and ecological sustainability as well as for the socio-economic benefit of poor forest dependent communities living in and around the forest. Managing forests with such aims may become source of livelihood for the locals, save the land from degradation and be a model of sustainable forest and land management. Also, there have not been much research done on the scientific effectiveness in the ANR plots by analysing the numbers of seedlings, saplings etc to assess their population. It needs to be promoted further.

\section{Acknowledgements}

The authors are thankful to Uttarakhand Forest Department officials of Kalsi Forest Division, Dehradun, Uttarakhand (India) for facilitating the field visit and providing necessary documentation and support. Authors also thank British Ecological Society (BES) for providing training and travel grant to attend Ecosummit 2016. Help received from the colleagues during various stages of analysis is thankfully acknowledged.

\section{References}

Bansal, A.K., Choudhary, P.R., Gogate, M.G. 2011. Assisted Natural Regeneration as a Tool for Forest Rehabilitation under JFM - an Analysis of Current Processes and Scope of Refinement. Indian Forester, 137(8a): 1-10.

Bay, D. 2002. Rehabilitation of degraded lands in humid zones of Africa. A report prepared for International Union of Forest Research Organizations, Global Forest Information Service (GFIS) project. Kumasi, Ghana.

FAO. 1985. Dipterocarps in South Asia. FAO Regional Office for Asia and Pacific, Bangkok.

Gadgil, M., Prasad, S.N., Ali, R. 1983. Forest Management and Forest Policy in India. Social Action, 33(2): 127-154.

Gautam, K.H., Devoe, N.N. 2006. Ecological and anthropogenic niches of Sal (Shorea robusta Gaertn. f.) forest and prospects for multiple-product forest management - a review. Forestry, 79: 81-101.

ICIMOD. 2000. Participatory Forest Management: Implications for Policy and Human Resources' Development in the Hindu Kush- Himalayas (Vol. IV).

Khan, M.L., Roy, J.P.N. and Tripathi, R.S., 1987. Population structure of some tree 
species in disturbed and protected subtropical forests of northwest India. Acta Ecol., 247-255.

Narayanmurti, D., Das, N. 1951. A preliminary note on adhesives, building boards, and moulding powders from tree's bark. Indian Forester, 77: 706708.

Negi, S.S. 1994. Indian Forestry through Ages, Indus Publishing Company, New Delhi, 77(8): 42-43.

O’Malley, L.S.S. 2011. Provincial geographies of India: Bengal, Bihar, and Orissa, Sikkim.

Pandey, S.K., Shukla, R.P. 2001. Regeneration strategy and plant diversity status in degraded Sal forests. Curr. Sci., 81: 95-102.

Sagar, R., Raghubanshi, A.S., Singh, J.S. 2003. Tree species composition, dispersion and diversity along a disturbance gradient in a dry tropical forest region of India. Forest Ecol. Manage., 186: 61-71.

Sannai, J. 2003. Assisted natural regeneration in China. Pages 29-32 in P. C. Dugan, P.B. Durst, D.J. Ganz, and P.J. McKenzie, editors. Advancing assisted natural regeneration (ANR) in Asia and the Pacific. Food and Agriculture
Organization of the United Nations Regional Office for Asia and the Pacific, Bangkok, Thailand.

Sapkota, I.P., Tigabu, M., Oden, P. 2009. Species diversity and regeneration of old growth seasonally dry Shorea robusta forests following gap formation. J. For. Res., 20: 7-14.

Satya, Upreti, D.K., Nayaka, S. 2005. Shorea robusta - an excellent host tree for lichen growth in India. Curr. Sci., 89: 594-595.

Shono, K., Cadaweng, A. Ernesto., Durst, B. Patrick. 2007. Application of Assisted Natural Regeneration to restore degraded tropical forestlands. Restoration Ecol., 15(4): 620-626.

Stainton, J.D.A. 1972. Forests of Nepal. John Murray, London.

Timilsina, N., Ross, M.S., Heinen, J.T. 2007. A community analysis of Sal (Shorea robusta) forests in the western Terai of Nepal. Forest Ecol. Manage., 241: 223234.

Webb, E.L., Sah, R.N. 2003. Structure and diversity of natural and managed Sal (Shorea robusta Gaertn.f.) forest in the Terai of Nepal. Forest Ecol. Manage., 176: 337-353.

\section{How to cite this article:}

Prateek Srivastava, Vasistha, H.B. 2017. Impact of Urbanisation on Natural Regeneration of Shorea robusta in Doon Valley (India). Int.J.Curr.Microbiol.App.Sci. 6(5): 1590-1600. doi: https://doi.org/10.20546/ijcmas.2017.605.173 